\title{
Prinsip dan Strategi Pembelajaran Mengatasi Lupa Perspektif Psikologi Pendidikan Islam
}

\author{
Muhammad Kosim ${ }^{1}$
}

\begin{abstract}
Abstrak
Setiap manusia pernah mengalami lupa. Di satu sisi lupa memang dibutuhkan ketika manusia dituntut untuk berpikir fokus pada objek tertentu. Namun lupa sering dimaknai secara negatif, seperti lupa kepada Allah, termasuk lupa pada materi pembelajaran sehingga lupa termasuk salah satu gangguan dalam belajar. Lupa sebagai gangguan belajar bisa diatasi dengan beberapa prinsip dan strategi pembelajaran berdasarkan teori-teori psikologi pendidikan, terutama dari kajian al-Quran dan Sunnah Nabi.
\end{abstract}

Kata kunci: strategi pembelajaran, lupa, psikologi pendidikan Islam

\section{A. Pendahuluan}

Ingat dan lupa merupakan dua sifat yang saling kontradiktif, akan tetapi dimiliki oleh setiap manusia. Di sisi lain, sifat lupa menjadi anugerah bagi manusia. Ketika manusia memikirkan satu objek, maka di saat itu pula objek-objek lain dilupakan. Jika saja dalam satu waktu seluruh objek yang pernah dilihat tetap diingat dalam waktu yang bersamaan, maka tentulah manusia akan mengalami kesulitan dalam berpikir dan bertindak.

Namun di sisi lain, lupa justru menjadi sifat negatif yang dapat mendatangkan berbagai persoalan dan termasuk menjadi salah satu gangguan mental. Bahkan dalam al-Qur'an disebutkan bahwa orangorang yang lupa dalam mengingat Allah dapat mengantarkannya kepada sifat munafik lagi fasik (Qs. At-Taubah/9: 67) serta dapat mengakibatkan kebinasaan (Qs. Al-Furqan/25: 18).

Demikian pula dalam perspektif pendidikan, sifat lupa justru menjadi salah satu gangguan dalam belajar. Sifat lupa dapat menghalangi seseorang dalam memahami dan menguasai suatu ilmu. Oleh karena itu, belajar yang ideal sesungguhnya berupaya untuk mengatasi sifat lupa tersebut secara

\footnotetext{
${ }^{1}$ Dosen Luar Biasa Fakultas Tarbiyah IAIN Imam Bonjol Padang
} 


\section{AT-TARBIUAH}

profesional dan proporsional sehingga ia menjadi seorang yang 'alim (orang yang berilmu) dan mengantarkannya untuk dekat kepada al-'Alim (Yang Maha Mengetahui).

Untuk mengatasi sifat pelupa yang menjadi gangguan belajar tersebut, dibutuhkan prinsip dan strategi pembelajaran yang tepat. Tulisan ini akan mencoba menguraikan suatu konsep tentang prinsip dan strategi pembelajaran dengan sudut pandang psikologi pendidikan Islam untuk mengatasi sifat lupa tersebut.

\section{B. Ingat dan lupa dalam perspektif Islam}

Dalam al-Qur'an banyak ditemukan ayat-ayat yang mendorong manusia agar senantiasa mengingat Allah. Ayat-ayat tersebut ada yang berbunyi: "afala tatadzakkarun" (tidakkah mereka ingat), "la'allahum yatadzakkarun" (agar mereka ingat), "qalilan ma tatadzakkarun” (sedikit sekali yang mereka ingat), "afala yadzdzakkarun (tidakkah mereka ingat), "la 'allahum yadzdzakkarun" (mudah-mudahan mereka ingat), "qalilan ma tadzakkarun" (amatlah sedikit kalian mengambil pelajaran), "wa li yatadzakkara ulul albab (dan supaya orang-orang yang berakal mengambil pelajaran), "Innama yatadzakkaru ulul albab" (sesungguhnya hanya orang-orang berakallah yang ingat, "wa ma yadzdzakkaru illa ulul albab" (dan tidak ada yang ingat kecuali orang-orang yang berakal).(Muhammad Utsman Najati, 2005: 338)

Demikian beragamnya ungkapan yang digunakan al-Qur'an untuk menyeru manusia agar senantiasa ingat. Bahkan Nabi yang diutus pun ditugaskan untuk mengingatkan kaumnya kepada Allah SWT serta ajaranajaranNya melalui al-Qur'an (Qs. Al-A'raf/7: 2). Ini menunjukkan bahwa begitu pentingnya manusia mengoptimalkan daya pikirnya agar tidak lupa, terutama kepada hal yang paling fundamental, yaitu mengingat Sang Pencipta, Allah SWT. Namun sifat lupa justru selalu dimiliki oleh manusia.

1. Makna lupa

Al-Qur'an menyinggung beberapa kali tentang lupa. Muhammad Utsman Najati (Muhammad Utsman Najati, 2005: 338-341) merumuskan tiga makna lupa, yaitu: pertama, lupa yang terjadi pada benak mengenai berbagai peristiwa, nama seseorang, dan informasi yang diperoleh seseorang sebelumnya, seperti firman-Nya dalam surat Al-A'la/87: 6. Kedua, lupa yang mengandung makna lalai. 
Makna kedua ini bisa dicontohkan dengan seseorang meninggalkan sesuatu di suatu tempat. Atau ia hendak berbincang-bincang dengan seseorang tentang berbagai hal, namun ia hanya ingat sebagiannya dan lupa sebagian lainnya, dan baru ingat kemudiannya. Sebagai contoh, ialah kisah tentang murid Musa as (Qs. Al-Kahfi/18: 63). Ketiga, lupa dengan pengertian hilangnya perhatian terhadap sesuatu hal, seperti tersirat dalam surat At-Taubah/9: 67 (Ibid., h. 336).

Selain itu, Abdul Mudjib mengemukakan bahwa kelupaan yang merupakan gangguan kepribadian manusia itu dapat dikelompokkan menjadi empat, yaitu: pertama, lupa untuk mengingat Allah, karena dirinya telah dikuasai setan (Qs. Al-Mujadalah/58: 16); kedua, mendustakan ayat-ayat Allah setelah beriman, sehingga dirinya menjadi lupa darinya (Qs. Al-A'raf/7: 146); ketiga, lupa karena kemunafikan, sehingga mereka telah lupa kepada Allah, maka Allah pun melupakan mereka (Qs. At-Taubah/9: 67); dan keempat, lupa karena ia mengikuti hawa nafsunya sehingga ia lupa kepada Allah (Qs. Al-Kahfi/18: 28) (Abdul Mujib dan Jusuf Mudzakir, 2001: 368369).

Jadi, dalam perspektif al-Qur'an, jenis lupa yang selalu diungkap adalah lupa kepada Allah sehingga ayat-ayat-Nya pun tidak dipatuhi. Akibatnya, lupa yang demikian akan mengantarkannya kepada kesengsaraan dan penderitaan.

\section{Zikir sebagai Terapi Lupa}

Terapi lupa yang timbul akibat kelalaian akan Allah adalah dengan ingat terus-menerus akan Dia, nikmat dan karunia-Nya, tanda-tanda kekuasaan-Nya pada ciptaan-ciptaan-Nya, akhirat, dan hari perhitungan. Al-Qur'an sendiri telah mengemukakan pentingnya zikir (ingat pada Allah) sebagai terapi bagi jenis lupa ini (Qs. AlKahfi/18: 24). Begitu pentingnya zikir sebagai terapi lupa, Allah SWT memerintahkan kepada manusia untuk berzikir kapan dan di mana pun ia berada, baik ketika berdiri, duduk, maupun berbaring (QS, Ali Imran, 3:190-191); ketika pagi maupun petang (Qs, alAhzab, 33:41-42).

Terapi lupa tersebut mesti dilakukan dengan zikir yang terusmenerus sehingga Allah hadir dalam hatinya secara terus-menerus, sekejap pun tidak pernah hilang. Hal ini mengisyaratkan pentingnya 


\section{AT-TARBIUAH}

pengulangan dalam belajar. Pengulangan ingat akan Allah biasanya akan membentuk kebiasaan bagi seseorang untuk selalu ingat dan memuji Allah. Sehingga kebiasaan ini pun menjadi mapan dan terpancang kuat dalam tingkah lakunya dan setiap saat selalu timbul tanpa upaya apapun. Allah pun, dengan demikian, menjadi selalu hadir dalam kalbunya. Ini adalah keadaan yang ingin diusahakan tercapainya oleh para sufi, dengan jalan mengulang-ulang latihan dan riadhah ruhaniah.

\section{Ingat dan Lupa dalam Psikologi Pendidikan}

Ingatan atau memori sesungguhnya tidak terlepas dari sistem syaraf pada otak manusia. Otak manusia memiliki satu triliun sel otak dengan 100 miliar sel aktif atau neuron dan 900 miliar sel lainnya sebagai "perekat", memelihara dan menyelubungi selsel aktif. Masing-masing neuron atau sel aktif tersebut mampu mengembangkan antara 2.000 dan 20.000 cabang (dendrite) yang sangat mirip dengan dahan-dahan dari sebuah pohon. Setiap dendrite menyimpan informasi, dan menerima masukan dari sel lain (Gordon Dryden dan Jeannette Vos, 2001: 112-118). Dengan demikian, otak memiliki kekuatan yang amat dahsyat dalam menerima dan mengolah informasi sehingga dapat menghasilkan ide-ide kreatif.

Otak itu sendiri memiliki beberapa organ. Salah satu organ paling penting dalam membentuk memori jangka panjang adalah organ hippocampus - berasal dari kata Yunani untuk "kuda laut" karena bentuknya mirip dengan binatang tersebut_-yang terletak di kedua belahan otak kanan dan kiri. Tegasnya, hippocampus adalah terminal penting yang menerima dan menyaring informasi, yang membantu memasukkan informasi itu ke dalam memori dan meneruskannya ke bagian-bagian otak lainnya. Tanpa hippocampus manusia mungkin bisa belajar, tetapi tidak bisa mengingat (Colin Rose dan Malcolm J. Nicholl, 2003: 70).

Adapun proses terjadinya memori atau ingatan tersebut terjadi pada tiga tahap, yaitu: pertama, penyandian; dimaksudkan sebagai transformasi informasi menjadi sandi atau representasi yang dapat diterima oleh memori; kedua, penyimpanan; yaitu retensi informasi yang telah disandikan tersebut; dan ketiga, pengambilan; yaitu proses dengan mana informasi diambil dari memori (pengingatan). 
Volume VI Nomor 1, Maret 2015

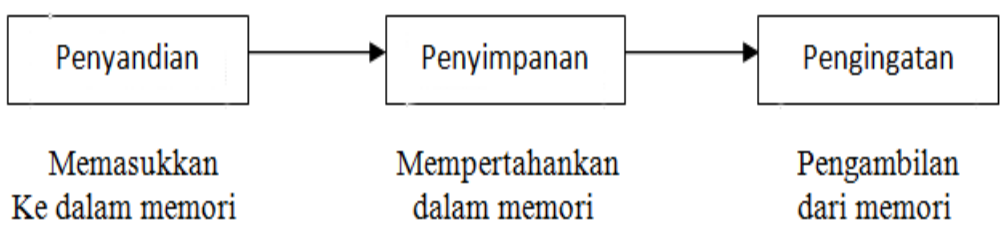

Gambar: Tiga tahap memori: teori memori yang menyatakan lupa sebagai kegagalan pada satu atau lebih stadium tersebut (Rita L. Alkitson, et. al., 1999: 479)

Tiga tahap itu mungkin bekerja secara berbeda dalam situasi yang mengharuskan kita menyimpan materi dalam hitungan detik (memori jangka pendek) dan dalam situasi yang mengharuskan kita menyimpankan materi untuk interval yang lebih panjang (memori jangka panjang) (Ibid., h. 542-543).

Memori jangka pendek tampaknya berfungsi sebagai ruang kerja mental dalam memecahkan masalah tertentu, seperti aritmatika mental dan menjawab pertanyaan tentang teks. Tetapi memori jangka pendek tampaknya tidak terlibat dalam pemahaman kalimat yang relatif sederhana. Memori jangka pendek juga berfungsi sebagai stasiun penghentian bagi memori permanen, di mana informasi mungkin tinggal di dalam memori jangka pendek sementara disandikan ke memori jangka panjang. Sedangkan informasi dalam memori jangka panjang biasanya disandikan menurut maknanya. Jika butir-butir yang harus diingat adalah bermakna tetapi hubungan di antaranya tidak, memori dapat diperbaiki dengan menambahkan hubungan yang bermakna yang memberikan jalur pengambilan. Semakin luas seseorang menguraikan makna, semakin baik memorinya (Ibid.,hlm. 543-544).

\section{Lupa sebagai Gangguan dalam Belajar}

Lupa (forgetting) ialah hilangnya kemampuan untuk menyebut atau memproduksi kembali apa-apa yang sebelumnya telah dipelajari. Secara sederhana, Gulo (1982) dan Reber (1988) mendefinisikan lupa sebagai ketidakmampuan mengenal atau mengingat sesuatu yang pernah dipelajari atau dialami. Dengan demikian, lupa bukanlah peristiwa hilangnya item informasi dan pengetahuan dari akal seseorang (Muhibbin Syah, 2008: 158). 


\section{A T-TARBIUAH}

Pada umumnya orang percaya bahwa lupa terutama disebabkan oleh lamanya tenggang waktu antara saat terjadinya proses belajar sebuah materi dengan saat pengungkapannya. Namun berdasarkan hasil-hasil penelitian, ternyata anggapan seperti itu nyaris tak terbukti.

1. Faktor-faktor penyebab lupa

Muhibbin Syah mengemukakan setidaknya ada enam faktor yang menyebabkan lupa tersebut (Ibid., hlm. 158-160) yaitu: Pertama, lupa dapat terjadi karena gangguan konflik antara item-item informasi atau materi yang ada dalam sistem memori siswa. Dalam interference theory (teori mengenai gangguan), gangguan konflik ini terbagi menjadi dua macam, yaitu: 1) proactive interference; 2) retroactive interference. Kedua, lupa dapat terjadi pada seorang siswa karena adanya tekanan terhadap item yang telah ada, baik sengaja ataupun tidak. Ketiga, lupa dapat terjadi pada siswa karena perubahan situasi lingkungan antara waktu belajar dengan waktu mengingat kembali (Anderson, 1990). Keempat, lupa dapat terjadi karena perubahan sikap dan minat siswa terhadap proses dan situasi belajar tertentu. Kelima, lupa dapat terjadi karena materi pelajaran yang telah dikuasai tidak pernah digunakan atau dihafalkan siswa. Menurut asumsi sebagian ahli, materi yang diperlakukan' demikian dengan sendirinya akan masuk ke alam bawah sadar atau mungkin juga bercampur aduk dengan materi pelajaran baru. Keenam, lupa tentu saja dapat terjadi karena perubahan urat syarat otak. Seorang siswa yang terserang penyakit tertentu seperti keracunan, kecanduan alkohol, dan gegar otak akan kehilangan ingatan atas item-item informasi yang ada dalam memori permanennya (Tohirim, 2008: 137-139).

2. Kiat mengurangi lupa dalam belajar

Kiat terbaik untuk mengurangi lupa adalah dengan cara meningkatkan daya ingat akal siswa. Banyak ragam kiat yang dapat dicoba siswa dalam meningkatkan daya ingatannya, antara lain menurut Barlow (1985), Reber (1988), dan Anderson (1990), adalah sebagai berikut.

Pertama, Over learning (belajar lebih) artinya upaya belajar yang melebihi batas penguasaan dasar atas materi pelajaran tertentu. Over learning terjadi apabila respons atau reaksi tertentu muncul setelah siswa melakukan pembelajaran atas respons tersebut dengan cara di luar kebiasaan. Misalnya, membaca asmaul husna sebelum 
belajar memungkinkan ingatan siswa terhadap materi keimanan lebih kuat.

Kedua, extra study time (tambahan waktu belajar), yaitu upaya penambahan alokasi waktu belajar atau penambahan frekuensi (kekerapan) aktivitas belajar. Penambahan alokasi waktu belajar materi tertentu berarti siswa menambah jam belajar, misalnya dari satu jam menjadi satu setengah jam.

Ketiga, mnemonic device (muslihat memori) yang sering juga hanya disebut mnemonic, berarti kiat khusus yang dijadikan "alat pengait" mental untuk memasukkan item-item informal ke dalam sistem akal siswa. Banyak kiat mnemonic yang dapat dilakukan, di antaranya adalah: 1) Rima (Rhyme), yakni sajak yang dibuat sedemikian rupa yang isinya terdiri atas kata dan istilah yang harus diingat siswa; 2) Singkatan, yakni terdiri atas huruf-huruf awal nama atau istilah yang harus diingat siswa; 3) Sistem kata kunci (key word system). Sistem kata kunci biasanya direkayasa secara khusus untuk mempelajari kata dan istilah asing, dan konon cukup efektif untuk pengajaran bahasa asing, Inggris misalnya. Sistem ini berbentuk daftar kata yang terdiri atas unsur-unsur sebagai berikut: a) kata-kata asing; b) kata-kata kunci, yakni kata-kata bahasa lokal yang paling kurang suku pertamanya memiliki suara/lafal yang mirip dengan kata yang dipelajari; dan c) arti-arti kata asing tersebut.

Keempat, pengelompokan (clustering), yaitu menata ulang item-item materi menjadi kelompok-kelompok kecil yang dianggap lebih logis dalam arti bahwa item-item tersebut memiliki signifikansi dan lafal yang sama atau sangat mirip. Penataan/pengelompokan ini direkayasa sedemikian rupa dalam bentuk daftar-daftar item materi seperti: daftar I terdiri atas nama-nama negara serumpun: Indonesia, Malaysia, Brunei, dan seterusnya; daftar II terdiri atas singkatansingkatan lembaga-lembaga negara: MPR, DPR, dan seterusnya.

Kelima, latihan terbagi. Lawan latihan terbagi (distributed practice) adalah latihan terkumpul (massed practice) yang sudah dianggap tidak efektif karena mendorong siswa melakukan cramming.Dalam latihan terbagi siswa melakukan latihan-latihan dengan alokasi waktu yang pendek dan dipisah-pisahkan di antara waktu-waktu istirahat.Upaya demikian dilakukan untuk menghindari 


\section{AT-TARBIUAH}

cramming, yakni belajar banyak materi secara tergesa-gesa dalam waktu yang singkat.

Keenam, Pengaruh letak bersambung. Untuk memperoleh efek positif dari pengaruh letak bersambung (the serial position effect), siswa dianjurkan menyusun daftar kata-kata (nama, istilah, dan sebagainya) yang diawali dan diakhiri dengan kata-kata yang harus diingat. Kata-kata yang harus diingat siswa tersebut sebaiknya ditulis dengan menggunakan huruf dan warna yang mencolok agar tampak sangat berbeda dari kata-kata yang lainnya yang tidak perlu diingat. Dengan demikian, kata yang ditulis pada awal dan akhir daftar tersebut memberi kesan tersendiri dan diharapkan melekat erat dalam subsistem akal permanen siswa.

Selain cara di atas, Hujair AH. Sanaky juga mengemukakan empat cara yang dapat dilakukan agar belajar tidak lupa, yaitu: 1) Review (pengulangan), yaitu mengingat dan merangkum apa yang telah dipelajari; 2) Self-assessment (penilaian diri sendiri), yaitu mengevaluasi perubahan-perubahan dalam hal pengetahuan, keterampilan dan perilaku; 3) Future planning (perencanaan masa yang akan datang), yaitu menentukan bagaimana siswa akan meneruskan kegiatan belajarnya setelah kelas selesai; dan 4) Expression final sentiments (pengungkapan sentimen-sentimen akhir), yaitu mengkomunikasikan pikiran-pikiran, perasaanperasaan, dan perhatian siswa yang mereka miliki pada akhir kelas (Hujair AH Sanaky, Lupa dalam Belajar, Handout PowerPoint, slide 16-17, (http://sanaky.com).

\section{Prinsip dan Strategi Pembelajaran Mengatasi Lupa}

Setelah memahami konsep dan teori tentang memori (ingatan) dan lupa yang terjadi pada manusia, baik secara normatif maupun kajian psikologis, maka dapat disimpulkan bahwa dalam proses pembelajaran diperlukan ingatan yang baik sehingga ia mampu menguasai beragam ilmu pengetahuan. Sementara lupa menjadi salah satu gangguan belajar yang dapat menghambat seseorang dalam menguasai beragam ilmu tersebut. Jadi, pembelajaran mesti dilakukan secara aktif (active learning) sehingga membantu peserta didik dalam menyimpan data dan informasi yang berkenaan dengan ilmu pengetahuan dalam memorinya. Untuk mencapai upaya tersebut, maka prinsip pembelajaran yang diterapkan hendaknya 
berbentuk PAIKEMI (Pembelajaran Aktif, Aktif, Inovatif, Kreatif, Efektif, Menyenangkan, dan Islami). Adapun prinsip pembelajaran dalam bentuk PAIKEMI tersebut dapat dirumuskan dalam beberapa prinsip, yaitu:

a. Prinsip Tazkiyah

Dalam psikologi Islam, sifat lupa dalam belajar juga dipengaruhi oleh keadaan jiwa seseorang. Mengenai hal ini, perlu dipahami kasus Imam Syafi'i dimana ia berkata:

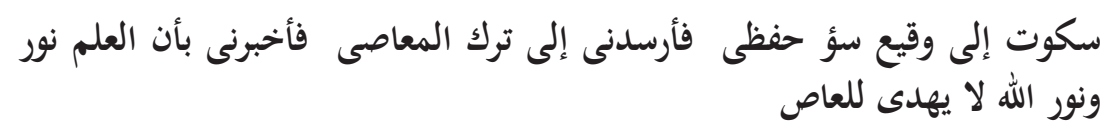

Ada dua hal yang perlu digarisbawahi dari nasihat Imam Waki' tersebut, yaitu pertama, untuk memperkuat ingatan diperlukan upaya meninggalkan perbuatan-perbuatan maksiat. Apa hubungan antara ingatan dengan maksiat? Dalam konsep psikologi, seseorang dikatakan sehat mentalnya bilamana terwujud keserasian antara fungsi-fungsi jiwa atau tidak ada konflik antara satu fungsi jiwa dengan lainnya. Fungsi jiwa antara lain berupa dorongan, perasaan, ingatan, pikiran. Jika salah satu fungsinya terganggu, maka akan berpengaruh terhadap lainnya. Orang yang berbuat maksiat akan terganggu perasaannya, ia akan memiliki perasaan bersalah dan berdosa, yang pada gilirannya akan mengganggu kekuatan ingatan dan juga pikirannya. Kedua, ilmu itu adalah cahaya Ilahi yang tidak akan tampak dan terlahirkan dari orang yang suka berbuat maksiat. (Muhaimin, 2006: 11)

Berdasarkan pengalaman Imam Syafi'i di atas maka proses pembelajaran tidak hanya upaya transfer of knowledge, akan tetapi mesti terjadi proses tazkiyah, baik tazkiyah nafsiyah, tazkiyah rohaniyah, maupun tazkiyah jasadiyah. Dengan demikian, secara ruhaniah peserta didik terhindar dari kemaksiatan sehingga ia mudah memahami suatu ilmu.

Dengan adanya proses tazkiyah ini, maka peserta didik akan terhindar dari gangguan kejiwaan atau abnormal. Secara garis besar keabnormalan tersebut dapat dibagi dalam dua bagian, yakni neurosa dan psikosa. Neurosa berkaitan dengan gangguan kejiwaan pada perasaan, dan psikosa pada gangguan pikiran. Perbedaan antara neurosa dan psikosa terletak pada perasaan, pikiran dan kepribadian 


\section{AT-TARBIUAH}

penderita. Neurosis yang terganggu hanya perasaannya, karena itu ia masih merasakan kesukaran yang dihadapinya sehingga kepribadiannya tidak memperlihatkan kelainan yang berarti dan masih berada dalam alam kenyataan. Sedang psikosis tidak saja perasaannya yang terganggu akan tetapi juga pifeiran dan kepribadiannya. Kepribadiannya tampak tidak padu karena integritas kehidupannya tidak berada dalam alam kenyataan yang sesungguhnya.(Yahya Jaya, 1994: 80-81)

Yahya Jaya mengemukakan bahwa kesehatan mental yang terganggu berpengaruh buruk terhadap kesejahteraan dan kebahagiaan. Gejala-gejalanya antara lain dapat dilihat dari segi perasaan, pikiran, .tingkah laku, dan kesehatan badan. Dari segi perasaan, gejalanya antara lain menunjukkan rasa gelisah, iri, dengki, sedih, risau, kecewa, putus asa, bimbang, dan rasa marah. Dari segi pikiran dan kecerdasan, gejalanya antara lain menunjukkan sifat lupa dan tidak mampu mengkonsentrasikan pikiran kepada suatu pekerjaan karena kemampuan berpikir menurun. Dari segi tingkah laku, antara lain menunjukkan kelakuan yang menyimpang dan tidak terpuji, seperti suka mengganggu lingkungan, mengambil milik orang lain, menyakiti dan memfitnah. Bila keadaan ini berlarut dan tidak mendapatkan penyembuhan, berkemungkinan penderita akan mengalami psikosomatik, yakni penyakit jasmani yang disebabkan oleh gangguan kejiwaan (Ibid.,hlm. 81).

Untuk menerapkan prinsip tazkiyah ini, maka diperlukan strategi pembelajaran sebagai berikut: 1) Hendaklah guru menanamkan kepada peserta didik bahwa belajar adalah ibadah; 2) Proses pembelajaran yang dilakukan seharusnya mengantarkan peserta didik kepada ingat kepada Allah (zikir). Apalagi zikir merupakan obat yang paling tepat untuk mengobati lupa, sebagaimana yang diungkapkan oleh Utsman Najati. Zikir tersebut bisa dilakukan ketika memulai pelajaran, terutama zikir istighfar. Zakiah Daradjat menegaskan taubat adalah cara yang paling efektif untuk menghindari sifat lupa; (Zakiah Daradjat, 2002: 45) ; 3) Dalam pelaksanaan roses pembelajaran, guru hendaknya menerapkan pendekatan qalbiyah sehingga lebih menyentuh perasaan dan emosional peserta didik. Sebab emosi sangat berpengaruh terhadap sistem penyimpanan memori jangka panjang (Colin Rose dan Malcolm J. Nicholl, op.cit., h. 125). 
b. Prinsip Belajar dengan melibatkan indera dan perbuatan

Confucius, sekitar 2400 tahun yang lalu berkata: What I hear, I forget, What I see, Iremember, What I do, I understand. Kemudian Mel Silberman, memodifikasi dan memperluas pernyataan di atas dengan ungkapan: What I hear, I forget; What I hear and see, I remember a little; What I hear, see, and ask quastions about or discuss with someone else, I begin to understand; What I hear, see, discuss, and do, I acquire knowledge and skill; What I teach to another, I master. (Melvin L. Silberman, 2006: 23-24)

Pernyataan Melvin ini ia dukung dengan hasil penelitian yang menunjukkan bahwa kebanyakan guru berbicara kurang lebih 100200 kata per menit. Jika siswa konsentrasi, mereka hanya dapat mendengar 50-100 kata per menit, atau setengah dari apa yang dikatakan guru. Itu karena siswa juga berpikir banyak selama mereka mendengarkan. Akan sulit menyimak guru yang bicaranya nerocos. Besar kemungkinan, siswa tidak bisa konsentrasi karena, sekalipun materinya menarik, berkonsentrasi dalam waktu yang lama memang bukan perkara mudah. Penelitian juga menunjukkan bahwa siswa mampu mendengarkan (tanpa memikirkan) dengan kecepatan 400 hingga 500 kata per menit. Ketika mendengarkan dalam waktu berkepanjangan terhadap seorang guru yang berbicara terlalu lambat, siswa cenderung menjadi jenuh, dan pikiran mereka mengembara entah ke mana.

Bahkan, sebuah penelitian lain juga menunjukkan bahwa dalam perkuliahan bergaya-ceramah, mahasiswa kurang menaruh perhatian selama 40\% dari seluruh waktu kuliah (Pollio, 1984). Mahasiswa dapat mengingat 70 persen dalam sepuluh menit pertama kuliah, sedangkan dalam sepuluh menit terakhir, mereka hanya dapat mengingat 20 persen materi kuliah (McKeachie, 1986). Tidak heran bila mahasiswa dalam kuliah psikologi yang disampaikan dengan gaya ceramah hanya mengetahui 8 persen lebih banyak dari kelompok pembanding yang sama sekali belum pernah mengikuti kuliah itu (Rickard, dkk., 1988). Bayangkan apa yang bisa didapatkan dari pemberian kuliah dengan cara seperti itu di perguruan tinggi! (Ibid.,hlm. 24) Oleh karena itu, prinsip pembelajaran yang perlu diterapkan adalah belajar yang melibatkan seluruh indra yang ada pada manusia secara optimal serta mampu melakukan secara aktif. 
Dalam al-Qur'an juga ditemukan beberapa ayat yang mendorong manusia agar mengoptimalkan inderanya, sebab semua itu kelak akan dimintai pertanggungjawabannya. Itu artinya bahwa indera penglihatan, pendengaran, dan hati yang dianugerahkan Allah kepada manusia sangat berperan besar dalam memahami ayat-ayat Allah, termasuk ilmu pengetahuan dalam proses pembelajaran (Qs. Al-Isra'/17: 36).

Dengan prinsip kedua ini, maka strategi pembelajaran dapat dilakukan dengan cara: 1) Mendesain metode pembelajaran yang melibatkan berbagai indra peserta didik secara aktif. Dalam hal ini, guru dituntut untuk menerapkan kreasi model-model pembelajaran yang aktif (active learning); 2) Hendaknya guru tidak terlalu mendominasi proses pembelajaran, akan tetapi memberi kebebasan/ kesempatan kepada peserta didik untuk mengemukakan ide-idenya sehingga mereka tidak hanya "menerima", akan tetapi mampu "melakukan", "merasakan" dan "mengamalkan" nilai-nilai yang dipelajari; dan 3) Menerapkan cooperative learning juga dibutuhkan dalam pelaksanaan proses pembelajaran yang melibatkan indra dan perbuatan peserta didik tersebut (Agus Suprijono, 2009; Hisyam, dkk., 2002). Kegiatan pembelajaran sebaiknya melibatkan peserta didik dalam bentuk kerja sama dengan temannya yang lain sehingga terjadi interaksi, gerak tubuh, tukar pikiran dan sebagainya.

c. Menerapkan pembelajaran yang berorientasi kepada multi kecerdasan

Howard Gardner, pakar psikologi dari Universitas Harvard, menyebutkan ada delapan kecerdasan manusia, yaitu: kecerdasan linguistik, kecerdasan logika dan matematika, kecerdasan musikal, kecerdasan spasial dan visual, kecerdasan kinestetik atau kecerdasan fisik, kecerdasan interpersonal, kecerdasan intrapersonal, dan kecerdasan naturalis(Gordon Dryden dan Jeannette Vos, op.cit., h. 120123). Sebelumnya dikenal kecerdasan intelektual (IQ). Lalu Daniel Goleman memperkenalkan EQ (Emotional Intelligence) pada tahun 1995 dengan menunjukkan bukti empiris dari penelitiannya bahwa orang-orang yang IQ tinggi tidak menjamin untuk sukses. EQ memberi rasa empati, cinta, motivasi, dan kemampuan untuk menanggapi kesedihan dan kegembiraan secara tepat (Daniel Goleman, 1993; T. Hermaya, 1999 dan Abdul Mujib dan Jusuf Mudzakir, 2001: 320). Kemudian muncul pula kecerdasan spiritual (Spiritual Quotient) yang dipopulerkan 
oleh Danah Zohar dan Ian Marshall (Danah Zohar dan Ian Marshall, 2000: vii), mendefinisikan SQ sebagai kecerdasan untuk menghadapi dan memecahkan persoalan makna dan nilai, yaitu kecerdasan untuk menempatkan perilaku dan hidup kita dalam konteks makna yang lebih luas dan kaya, kecerdasan untuk menilai bahwa tindakan atau jalan hidup seseorang lebih bermakna dibandingkan dengan yang lain. Bahkan mereka menegaskan bahwa SQ sebagai kecerdasan tertinggi manusia sekaligus sebagai landasan untuk memfungsikan IQ dan EQ secara efektif (Ibid., h. 4-5).

Selain itu, dikenal pula teori tentang otak kiri dan otak kanan. Secara umum otak kiri memainkan peranan dalam pemprosesan logika, kata-kata, matematika, dan urutan yang disebut pembelajaran akademis. Sementara otak kanan berusaha dengan irama, rima, musk, gambar dan imajinasi yang disebut dengan aktivitas kreatif. Proses pembelajaran diharapkan mampu menyeimbangkan kedua belahan otak ini.

Teori-teori kecerdasan di atas mesti menjadi perhatian guru dalam proses pembelajaran. Artinya, guru diharapkan berupaya menerapkan pembelajaran berorientasi kepada multi kecerdasan tersebut. Dengan begitu diharapkan pesan yang diterima peserta didik dapat tersimpan dengan baik dalam memorinya.

Pentingnya pembelajaran multikecerdasan ini, khususnya terkait dengan kecerdasan intelektual, emosional, dan spiritual, juga tersirat dalam tugas Nabi SAW sebagaimana firman-Nya dalam surat AlBaqarah/2: 151)

Prinsip ketiga ini dapat dilakukan dengan strategi berikut: 1) Pembelajaran dilakukan dengan kombinasi pendekatan dan metode yang bervariasi dengan memperhatikan tipe kecerdasan yang ditekankan; 2) Pembelajaran hendaknya didesain dengan menyeimbangkan otak kiri dan kanan; 3) Pendekatan kasih sayang, keteladanan dan emosional perlu ditekankan dalam mengoptimalkan kecerdasan emosional dan spiritual, disamping pendekatan rasional untuk kecerdasan intelektual; dan 4) Senantiasa memberikan motivasi kepada peserta didik sehingga kecerdasannya tumbuh dan berkembang dengan baik.

d. Menerapkan proses pembelajaran yang memperhatikan gaya 


\section{AT-TARBIUAH}

\section{belajar peserta didik}

Umumnya, peserta didik memiliki penekanan terhadap salah satu kecerdasan di antara kecerdasan lainnya. Oleh karena itu, mereka juga memiliki gaya belajar yang berbeda pula. Setidaknya ada tiga gaya belajar, yaitu: pertama, pelajar haptik, dari kata Yunani yang berarti "bergerak bersama", yaitu orang yang belajar paling baik ketika mereka terlibat, bergerak, mengalami, dan mencoba-coba. Gaya ini juga biasa disebut dengan gaya kinestetik; kedua, pelajar visual, yang belajar paling baik ketika mereka melihat gambar-gambar yang merkea pelajari. Sebagian kecil mereka berorientasi pada "teks tercetak" dan dapat belajar melalui membaca; dan ketiga, pelajar auditorial, yang belajar paling baik melalui suara, seperti musik dan berbicara. ${ }^{2}$ (Gordon Dryden dan Jeannette Vos, op.cit.,hlm. 129-131)

Untuk memudahkan peserta didik dalam menerima materi pembelajaran, maka salah satu cara yang efektif dilakukan oleh guru adalah dengan mengenal gaya belajar peserta didik. Dengan memahami gaya belajar tersebut, maka strategi yang dibutuhkan adalah: 1) Guru diminta untuk mendesain metode yang sesuai dengan gaya belajar tersebut. Jika peserta didik tersebut relatif banyak dengan gaya belajar yang beragam, maka guru mesti menerapkan metode pembelajaran yang bervariasi; dan 2) Menghargai perbedaan individual dengan keragaman kecenderungan cara belajar peserta didik.

\section{e. Memanfaatkan Media dalam Pembelajaran}

Media atau alat pendidikan meliputi segala sesuatu yang dapat membantu proses pencapaian tujuan pendidikan. ${ }^{3}$ (Zakiah Daradjat, Ilmu Pendidikan Islam, (Jakarta: Bumi Aksara, 1992),hlm. 80) Media dapat membantu pendidik untuk menyampaikan materi kepada peserta didik. Media juga dapat membantu peserta didik untuk tidak mudah lupa dalam proses pembelajaran tersebut.

Terutama bagi peserta didik yang masih di usia anak-anak, umumnya mereka sulit berpikir yang abstrak, maka keberadaan media sangat membantu. Meskipun demikian, kalangan dewasa pun membutuhkan media pembelajaran sebagai upaya melibatkan berbagai macam indera, seperti melihat dan mendengar.

${ }^{2}$ Gordon Dryden dan Jeannette Vos, op.cit.,hlm. 129-131

${ }^{3}$ Zakiah Daradjat, Ilmu Pendidikan Islam, (Jakarta: Bumi Aksara, 1992),hlm. 80 
Ali Al-Jumbulati menyebutkan tentang prinsip ini dengan mengatakan bahwa dalam pekerjaan mengajar, alat-alat peraga tersebut merupakan sarana pembuka cakrawala yang lebih luas, yang berlawanan dengan kebiasaan merumuskan kalimat-kalimat yang ditulis atau diucapkan. Di samping itu, alat peraga juga menjadikan pengetahuan anak bersentuhan langsung dengan pengalaman indrawi yang hakiki. Maka dari itu makna yang terkandung di dalam metoda ini adalah lebih memudahkan anak memahami pelajaran dan meminimalisir kesalahan dalam penerimaan ilmu yang diajarkan (Ali al-Jumbulati, 1994: 201).

Nabi Muhammad SAW dalam mendidik para sahabatnya juga selalu menggunakan alat atau media, baik berupa benda maupun nonbenda. Salah satu alat yang digunakan Rasulullah dalam memberikan pemahaman kepada para sahabatnya adalah dengan menggunakan gambar. Diriwayatkan oleh Imam Ahmad dan al-Hakim dari Abdullah bin Mas'ud, ia berkata, "Rasulullah membuatkan kami garis:

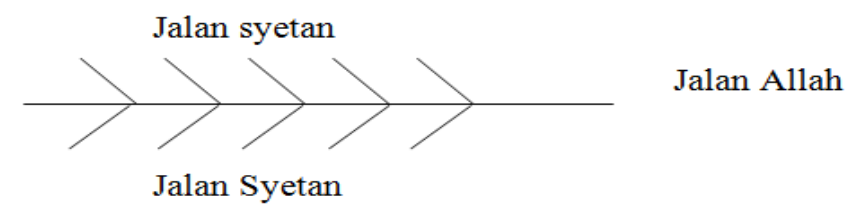

Lalu bersabda, "Ini jalan Allah. 'Kemudian membuat garis-garis di sebelah kanan dan kirinya, dan bersabda, "Ini adalah jalan-jalan (setan)." Yazid berkata, "(Garis-garis) yang berpencar-pencar." Rasulullah SAW bersabda, "Di setiap jalan ada setan yang mengajak kepadanya. Kemudian beliau membaca Q.S. al-An'am/6: 153.

Hadis di atas terlihat jelas bahwa Rasulullah SAW menggunakan garis-garis sebagai alat pendidikan untuk menjelaskan apa yang ingin beliau sampaikan kepada para sahabatnya. (Fadhl Ilahi, 2006: 127128; Hafidz Abdurrahman, 2005: 80) Perlu pula ditegaskan bahwa dalam konteks pendidikan Islam, M. Arifin menyebutkan alat-alat pendidikan harus mengandung nilai-nilai operasional yang mampu mengantarkan kepada tujuan pendidikan Islam yang sarat dengan nilai-nilai (M. Arifin, 1993: 145). Nilai-nilai tersebut tentunya berdasarkan kepada dasar atau karakteristik pendidikan Islam itu sendiri.

Demikian pentingnya media pembelajaran, maka seorang 


\section{AT-TARBIUAH}

pendidik mesti memiliki strategi tertentu pula, di antaranya: 1) Guru mesti merancang media pembelajaran yang sesuai dengan materi sehingga membantu peserta didik untuk mudah mengingat ilmu yang diberikan; 2) Media pembelajaran yang diterapkan hendaklah disesuaikan dengan tingkat perkembangan peserta didik; dan 3) Media pembelajaran hendaklah disusun untuk mencapai kompetensi yang diinginkan dan ditampilkan secara menarik sehingga merangsang peserta didik untuk mengingatnya dengan baik.

\section{E. Penutup}

Pembelajaran aktif dalam perspektif psikologi pendidikan Islam tidak hanya menekankan pada aspek jasmaniah saja, seperti gerak tubuh komunikasi verbal yang baik, dan kelengkapan alat/media, akan tetapi lebih dari itu, pembelajaran mesti dilakukan dengan memperhatikan dimensi rohaniyah. Salah satu penyebab lupa yang menjadi gangguan belajar bagi peserta didik bisa disebabkan oleh kotornya rohani seseorang. Oleh karena itu, prinsip tazkiyah menjadi prinsip utama dalam menghindarkan peserta didik dari sifat lupa yang dapat mengganggu proses belajarnya.

Selain itu, kemampuan guru/pendidik dalam mengenal karakter peserta didik, baik dari tingkat kecenderungan kecerdasan yang dimiliki hingga kepada gaya belajar yang disukai, sangat dibutuhkan. Semua ini menjadi pertimbangan mendasar untuk mendesain kegiatan pembelajaran dengan seperangkat metode, pendekatan, alat/media yang digunakan sehingga membantu peserta didik untuk memahami, menguasai dan mengamalkan setiap ilmu yang dibelajarkan.

Masih banyak prinsip dan strategi lain yang dapat dilakukan. Kajian dan penelitian lebih lanjut perlu dilakukan sehingga ditemukan ide-ide kreatif yang lebih bermanfaat bagi pengembangan pendidikan Islam, khususnya dalam perspektif psikologi pendidikan Islam dalam mengatasi, paling tidak mengurangi lupa sebagai gangguan dalam belajar. 


\section{BIBLIOGRAFI}

Abdul Mujib dan Jusuf Mudzakir, Nuansa-nusansa Psikologi Islam, Jakarta: PT RajaGrafindo Persada, 2001

Agus Suprijono, Cooperative Learning; Teori dan Aplikasi, Yogyakarta:

Pustaka Pelajar, 2009

Ahmad Warson Munawwir, Kamus Arab - Indonesia, Yogyakarta, Pesantren al-Munawwir, 1984

Ali al-Jumbulati, Dirasatun Muqaaranatun fit Tarbiyyatil Islamiyyah,

Penj. H. M. Arifin, Jakarta: Rineka Cipta, 1994

Colin Rose dan Malcolm J. Nicholl, Accelerated Learning For the $21^{\text {st }}$

Century, Penj. Purwanto, Bandung: Nuansa, 2003, cet. ke-4

Danah Zohar dan Ian Marshall, SQ: Spiritual Intelligence - The Ultimate

Intelligence, Bloomsbury, Great Britain tahun 2000

Daniel Goleman, Emotional Intelligences, New York: HarperCollins (Basic

Books), 1993, alih bahasa T. Hermaya, judul: Emotional Intelligence,

Jakarta: Gramedia Pustaka Utama, 1999

Dedeng Rosidin, Insan Rabbani, (http://persis.or.id), didownload tanggal

31 Desember 2009.

Fadhl Ilahi, Muhammad SAW Sang Guru yang Hebat; Sirah Nabi sebagai

Guru Berdasarkan al-Qur'an dan Hadis-hadis Shahih, (Surabaya:

Pustaka eLBA, 2006),

Gordon Dryden dan Jeannette Vos, Revolusi Cara Belajar (The Learning Revolution); Bandung: KAIFA, 2001

Hafidz Abdurrahman, Membangun Kepribadian Pendidik Umat;

Ketauladanan Rasulullah SAW di Bidang Pendidikan, Ciputat: Wadi

Press, 2005

Hisyam, dkk, Strategi Pembelajaran Aktif, Yogyakarta: CTSD IAIN Sunan Kalijaga, 2002

Hujair AH Sanaky, Lupa dalam Belajar, Handout PowerPoint, (http:// sanaky.com).

Ibnu Manzhur, Lisan al-arabi, (Baerut, Dar al-Ihya al-Turats al-Arabi, 1988, jilid vii

M. Arifin, Ilmu Pendidikan Islam, Jakarta: Bumi Aksara, 1993, edisi I, cet. ke-2

Melvin L. Silberman, Active Learning; 101 Cara Belajar Aktif, Penj. Raisul Muttaqien, Jakarta: Nusamedia, 2006, cet. ke-3

Muhaimin, Nuansa Baru Pendidikan Islam; Mengurai Benang Kusut Dunia Pendidikan,(Jakarta: Rajawali Pers, 2006 


\section{AT-TARBIUAH}

Muhammad Utsman Najati, Psikologi dalam al-Qur'an; Terapi Qur'an dalam Penyembuhan Gangguan Jiwa, Penj. M. Zaka al-Farisi, Bandung: Pustaka Setia, 2005

Muhibbin Syah, Psikologi Pendidikan dengan Pendekatan Baru, Bandung: Remaja Rosdakarya, 2008, cet. ke-14

Rita L. Alkitson, et. al. Introduction to Psychology, 11 th ed. Pej. Widjaja Kusuma, Batam: Interaksara, 1999

Tohirim, Psikologi Pembelajaran Pendidikan Agama Islam, Jakarta: Rajawali Pers, 2008

Toto Tasmara, Kecerdasan Ruhaniah (Transcendental Intelligence); Membentuk Kepribadian yang Bertanggung Jawab, Profesional, dan Berakhlak, Jakarta: Gema Insani Press, 2001

Yahya Jaya, Spiritualisasi Islam dalam Menumbuhkembangkan Kepribadian dan Kesehatan Mental, Jakarta: Ruhama, 1994

Yusuf Murad, Mahadi' 'ilm al-Nafs al-'Am, Mesir: Dar al-Ma'arif, tt.

Zakiah Daradjat, Psikoterapi Islam, Jakarta: Bulan Bintang, 2002 